\title{
A pilot numerical simulation case study for chemical EOR feasibility evaluation
}

\author{
Xianchao Chen ${ }^{1} \cdot$ Qihong Feng $^{1} \cdot$ Xianghong $\mathrm{Wu}^{2} \cdot{\text { Guoliang } \mathrm{Zhao}^{2}}^{2}$
}

Received: 8 December 2014/ Accepted: 17 May 2015/Published online: 2 June 2015

(c) The Author(s) 2015. This article is published with open access at Springerlink.com

\begin{abstract}
Because of high oil price and technology advancement in recent years, chemical EOR is becoming an important option for maintaining sustainable efficient development for mature reservoirs in the future. In this paper, an integrated numerical simulation approach is adopted for Palouge oilfield in South Sudan for chemical EOR feasibility evaluation. The chemical EOR methods are preliminarily screened for the main oil-bearing zones, and the advantages and disadvantages for chemical flooding are analyzed by comparing technical parameter limits with oilfield parameters. Specifically, the pilot oil zone and areal position selection was determined using a comprehensive method, which is based on zonal injection plan and application experiences. Chemical EOR simulation is performed for sensitivity analysis and different scenarios prediction. Three technical indicators are employed to evaluate the EOR efficiency. Some key physiochemical factors with uncertainty are also analyzed in detail, and this will provide unusual useful information for comprehensive feasibility evaluation. The proposed technical evaluation procedure provides a helpful guidance for chemical EOR feasibility assessment in other analogous reservoirs.
\end{abstract}

Xianchao Chen

mangix2010@gmail.com

1 School of Petroleum Engineering, China University of Petroleum (East China), Yangtze River Road West NO. 66, Qingdao, China

2 Research Institute of Petroleum Exploration and Development, CNPC, Xueyuan Road NO. 20, Haidian District, Beijing, China
Keywords Pilot numerical simulation - Chemical EOR · Feasibility evaluation - EOR screening methods . Uncertainty analysis

\section{Introduction}

Although the alternative energy is attracting worldwide focus, the petroleum industry accounts for the main energy supply in the following decades. With the decline in new oil discoveries in recent years, EOR technology is a good option to meet the energy demand in years to come. The increasing energy demand and the high oil price greatly spur the EOR field applications all around the world. The emerging economies have a huge need for energy supply, which leads to relative high oil price (Sandrea and Sandrea 2007). As a result, EOR methods, including miscible/immiscible gas EOR, thermal EOR, and chemical EOR, turn into economic methods. In addition, the technique advancements push EOR methods on the table of the oilfield manager (Al-Mutairi and Kokal 2011).

The worldwide EOR projects in the past decade have increased (Thomas 2008). Thermal methods, specifically steam injection, still dominate as the preferred EOR method for heavy oil reservoirs (Worldwide 2010). It is clear that thermal and chemical methods are most frequently used in sandstone reservoirs compared to other lithology (Manrique et al. 2010). In general, sandstone reservoirs show a highest potential to implement chemical EOR methods. However, chemical EOR projects have made a relatively small contribution to the world's oil production during the last decades (Alvarado and Manrique 2010). Especially, China is the country with the largest oil production resulting from chemical EOR projects (Chang et al. 2006; Gu et al. 1998; Hongyan et al. 2009; Pu 2009). 
Polymer flooding is recently gaining interest for viscous oil reservoirs (Wassmuth et al. 2009) and offshore fields (Spildo et al. 2009). Chemical EOR technology is dramatically evolving better than 30 years ago due to more experiences, better understanding, better modeling, and better chemicals at lower cost (Alvarado et al. 2011; Koning et al. 1988; Li et al. 2003; Manrique et al. 2000; Meyers et al. 1992; Vargo et al. 2000). If the oil prices keep on high level, oil companies can make a relative good return by properly implementing chemical EOR methods.

In this study, Palouge structure is the target reservoir. It is a high temperature $\left(82^{\circ} \mathrm{C}\right)$, high permeability $(\sim 4.8 \mathrm{D})$, bottom \& edge water drive sandstone reservoir located in Melut Basin of South Sudan (Yeow Chong et al. 2013). The oil production is declining and the water cut is at high stage after the primary recovery process. In addition, it is predicted that limited secondary oil recovery expectation is from water injection development plan because of severe mobility ratio and heterogeneity. These conditions make the chemical EOR technology an important option for maintaining sustainable efficient development for Palouge structure in the future.

The EOR feasibility needs to be carefully evaluated before deployment. Therefore an integrated numerical simulation procedure for chemical feasibility study is adopted. According to the results of the water injection development plan, a pilot zone is firstly selected. Then chemical EOR simulation is performed for parameters' sensitivity and uncertainty analysis. Based on all the scenario simulation results and field application experiences, the recommended EOR method is finally determined.

\section{EOR methods screening}

\section{EOR methods screening process}

Before performing the EOR methods screening, it is necessary to collate and sort the field data (Al-Adasani and Bai 2010; Worldwide 2010). The screening parameters are the average values of the whole reservoir and some unavailable screening data is obtained using empirical equation. The zones with little reserves are not included in screening process, EOR screening will be performed on main oilbearing zones (Yabus II-Yabus VIII). Since the reservoir and fluid screening data have been selected and the SPE EOR screening criteria have been chosen, the EOR methods screening process is conducted using go-not-go method (Taber et al. 1996).

According to the screening result, the oil viscosity is too high for miscible gas. Immiscible gas is not considered due to the unavailability of sufficient gas. Thermal method is not recommended due to high investment and relative high water cut. The polymer is preferably recommended for all oil zones, and the ASP is recommended for zones II-V.

\section{Primary chemical EOR feasibility evaluation}

The main parameter limits for chemical flooding are summarized according to actual field applications survey, which is very useful for the following pilot design and risk assessment (Al-Adasani and Bai 2010; Alvarado and Manrique 2010; Li et al. 2008; Taber et al. 1997). Then the parameters of main oil zones are compared with the technical limit (Table 1). It can be seen that Yabus VI is not suitable for chemical flooding for lack of injectors, wide well spacing, high oil viscosity, strong edge water drive, and high temperature. Figure 1 also shows that Yabus IVVI locate in the feasible viscosity area for chemical flooding.

These comparisons indicate the advantages and disadvantages for chemical flooding in Palouge Structure. The favorable factors for chemical flooding include: relatively high net thickness and high oil saturation, high porosity, high permeability, and high acid content. The adverse factors for chemical flooding include: edge water drive, high reservoir temperature, irregular well pattern, and wide well spacing.

As the disadvantages are difficult to mitigate as soon as possible, the chemical flooding may not be suitable for the full-field implementation at present. Hence chemical agents are injected into the pilot to see if the chemical flooding is suitable for the pilot reservoir condition. Then the enhanced oil recovery factor or the potential can be evaluated more acutely and realistically for the whole field.

\section{Pilot selection and dynamic model set-up}

\section{Zonal water injection plan review}

The EOR technologies are the following production methods after water injection, so EOR plans are based on zonal injection plan. Some main features of zonal injection are listed as following:

(1) Zonal water injection is designed in feasible area of Yabus IV and V where remaining oil is abundant and formation pressure is insufficient.

(2) Injectors have good connections with neighboring producers and the nearby formation property is relatively good.

(3) Zonal injection is based on workover scenario.

(4) Convert some existing wells and drill new producers to form an inversed nine-spot well pattern. 
Table 1 The main parameter comparison of the main oil-bearing zones

\begin{tabular}{|c|c|c|c|c|}
\hline Parameters & Range & Yabus IV & Yabus V & Yabus VI \\
\hline Net thickness (m) & $3.2-19$, avg.8.76 & 7.6 & 11.49 & 18.9 \\
\hline Depth (m) & 211-2,139, avg.893 & 1,271 & 1,306 & 1,340 \\
\hline Edge/bottom water & Rarely & Medium & Medium & Strong \\
\hline Porosity (\%) & $18-35$, avg.26 & 28.9 & 26.7 & 26.4 \\
\hline Permeability (mD) & $326-7,200$, avg.1397 & 4,354 & 5,631 & 6,025 \\
\hline Oil saturation (\%PV) & 58-74.8, avg.69 & 79.1 & 80.3 & 77 \\
\hline Oil viscosity (cp) & 7-417, avg.28.4 & 21 & 29 & 46.9 \\
\hline Oil gravity (API) & $14-35$, avg.25 & 26.2 & 25.3 & 24.4 \\
\hline Acid (mg KOH/g oil) & $0.01-3.11$, avg.1.49 & 1.28 & 2.63 & 2.13 \\
\hline Salinity (ppm) & $4,454-29,000$, avg.6187 & 5,509 & 5,509 & 6,550 \\
\hline Temperature $\left({ }^{\circ} \mathrm{C}\right)$ & $23-90$, avg.57.86 & 80.5 & 82 & 83.2 \\
\hline Well pattern & Mostly five spot & Irregular & Irregular & No injectors \\
\hline Well spacing (m) & $50-300$, avg. 140 & $250-300$ & $250-301$ & $>300$ \\
\hline
\end{tabular}

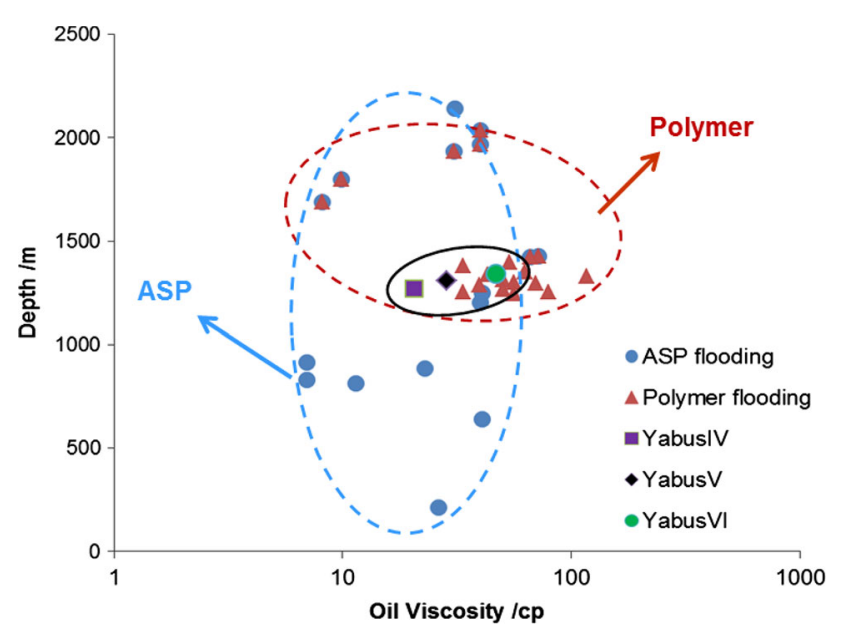

Fig. 1 The reservoir data comparison between China and Palouge Structure

\section{Pilot selection}

The pilot should not be determined only by the remaining oil distribution, it should consider many other factors (Sandoval et al. 2010). The main paying zone Yabus IV, V, and VI are the target candidate zones for the chemical selection. By referring to the geology conditions and zone water flooding plan, the target zone is screened, as seen in Table 2. Zone Yabus VI fails the screening and zone Yabus IV and Yabus V pass the screening process, however the well pattern needs infilling before chemical flooding implementation.

The Palouge Structure is divided into seven regions by faults, structure, sand body, and water contact. The candidate areal locations are then screened by analyzing the structural high, net thickness, sand connectivity, edge water, remaining oil abundance area et al. By summarizing all analysis in Table 3 , the region 2 is selected as the pilot location region candidate. However, the region 2 is too big for pilot test, hence the south part of region 2 is selected as the recommended pilot area as this pilot is surrounded by faults in three directions (East, West, South), which is relatively closed and less affected by other adjacent wells (as shown in Fig. 2).

\section{Sector dynamic model set-up}

The commercial softwares Petrel and Eclipse are used to set-up the model. The zonal injection dynamic model is imported from Eclipse to Petrel, then the sector part is cut from the imported model in Petrel. The grids of the main oil bearing zones are refined both in vertical and horizontal directions. The processed properties of the sector dynamic model are imported back to Eclipse. The well locations of the pilot area are shown in Fig. 3.

The properties are used to initialize the sector model. This belongs to non-equilibrium initialization. As there is no water injection history, it needs to calibrate the sector model by results comparison between the full-field prediction and sector prediction for water injection scenarios. The two predictions have little difference in oil rate and water cut (Figs. 4, 5), so the sector model can be used to predict pilot chemical flooding.

\section{Chemical EOR parameters sensitivity}

\section{Physiochemical data preparation}

Based on the chemical formulation selection and evaluation experiments, the physiochemical data for Eclipse chemical EOR simulation are prepared according to the following principles (Maheshwari 2011; Pitts et al. 2006): 
Table 2 The oil zone selection for the chemical pilot

\begin{tabular}{|c|c|c|c|c|}
\hline Parameters & Favorable condition & Yabus IV & Yabus V & Yabus VI \\
\hline OOIP (MMSTB) & Big reserve & 147.3 & 164.7 & 160.9 \\
\hline $\begin{array}{l}\text { Chemical screening } \\
\text { results }\end{array}$ & P/ASP & P/ASP & P/ASP & $\mathrm{P}$ \\
\hline $\begin{array}{l}\text { Injection-production } \\
\text { pattern }\end{array}$ & Regular pattern with small spacing & $\begin{array}{l}\text { Irregular pattern with } \\
\text { wide spacing }\end{array}$ & $\begin{array}{l}\text { Irregular pattern with } \\
\text { wide spacing }\end{array}$ & No injectors \\
\hline Barrier & $\begin{array}{l}\text { Stable continuous barrier with } \\
\text { adjacent oil zones }\end{array}$ & Yes & Yes & $\begin{array}{l}\text { No (bottom has no } \\
\text { continuous barrier) }\end{array}$ \\
\hline Bottom/edge water & No aquifer & Edge water & Edge water & $\begin{array}{l}\text { Bottom water and edge } \\
\text { water }\end{array}$ \\
\hline Sand connectivity & Good connectivity & Relatively continuous & Continuous & Continuous \\
\hline Results & & Target & Target & Fail \\
\hline
\end{tabular}

Table 3 The summary of the pilot selection

\begin{tabular}{|c|c|c|c|c|c|c|c|c|}
\hline Region & Evaluation property & 1 & 2 & 3 & 4 & 5 & 6 & 7 \\
\hline \multirow[t]{5}{*}{ Yabus IV } & Structural high & & $\sqrt{ }$ & & & & $\sqrt{ }$ & $\sqrt{ }$ \\
\hline & Net thickness & & $\sqrt{ }$ & & & & $\sqrt{ }$ & $\sqrt{ }$ \\
\hline & Sand connectivity & & $\sqrt{ }$ & $\sqrt{ }$ & & & & \\
\hline & Edge water & & $\sqrt{ }$ & $\sqrt{ }$ & $\sqrt{ }$ & & $\sqrt{ }$ & $\sqrt{ }$ \\
\hline & $\begin{array}{l}\text { Remaining } \\
\text { abundance }\end{array}$ & & $\sqrt{ }$ & & $\sqrt{ }$ & & $\sqrt{ }$ & \\
\hline \multirow[t]{5}{*}{ Yabus V } & Structural high & & $\sqrt{ }$ & & & & $\sqrt{ }$ & $\sqrt{ }$ \\
\hline & Net thickness & & $\sqrt{ }$ & $\sqrt{ }$ & & & & $\sqrt{ }$ \\
\hline & Sand connectivity & $\sqrt{ }$ & $\sqrt{ }$ & $\sqrt{ }$ & & & & \\
\hline & Edge water & & $\sqrt{ }$ & $\sqrt{ }$ & $\sqrt{ }$ & & & $\sqrt{ }$ \\
\hline & $\begin{array}{l}\text { Remaining } \\
\text { abundance }\end{array}$ & $\sqrt{ }$ & $\sqrt{ }$ & $\sqrt{ }$ & & & $\sqrt{ }$ & $\sqrt{ }$ \\
\hline
\end{tabular}

(1) Honor the lab results and make the most of them;

(2) Perform necessary modifications according to the actual field applications and experiences;

(3) For some unavailable data, take the data from previous study for references.

Table 4 shows the detailed information of data preparation for chemical flooding simulation.

\section{Water injection base case}

As the target zones (Yabus IV and Yabus V) have constant barriers with adjacent layers, only the two zones are set active for the following parameter sensitivity simulation. The oil recovery of Yabus IV and Yabus V decreases as the injection rate increases (Fig. 6). Considering the development time limit and the injection ability decrease of the following chemical flooding, injection rate $0.16 \mathrm{PV} / \mathrm{a}$ (Pore Volume per year) is selected as the water comparison base case. Considering the development cost and China's chemical flooding experiences, the recommended chemical injection timing is when the water cut reaches $90 \%$.

\section{Sensitivity evaluation indexes}

Three indexes are used to evaluate the effect of the chemical flooding sensitivity analysis: the incremental recovery factor, which is the enhanced oil recovery compared with the base water flooding case; the chemical agent efficiency is defined as the enhanced oil per unit chemical agent (tons incremental oil/tons chemical); the composite index, which is defined as the product of the incremental recovery factor and the chemical agent efficiency. These three indexes will be used to evaluate the comprehensive effect.

\section{EOR parameters sensitivity analysis process}

For polymer flooding, it can be seen in Table 5 that the incremental recovery factor increases as the polymer injected pore volume increases. However, the polymer utilization efficiency will decrease as the injected pore volume increases. The composite index shows that $0.4 \mathrm{PV}$ is relatively appropriate. The incremental recovery factor 


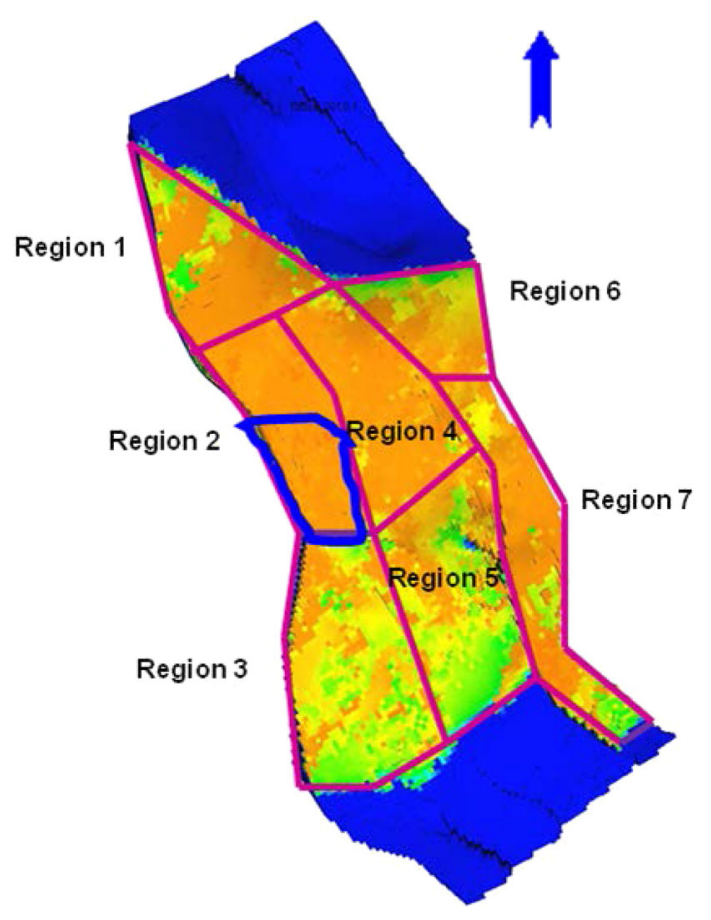

Fig. 2 The candidates for pilot plane location selection

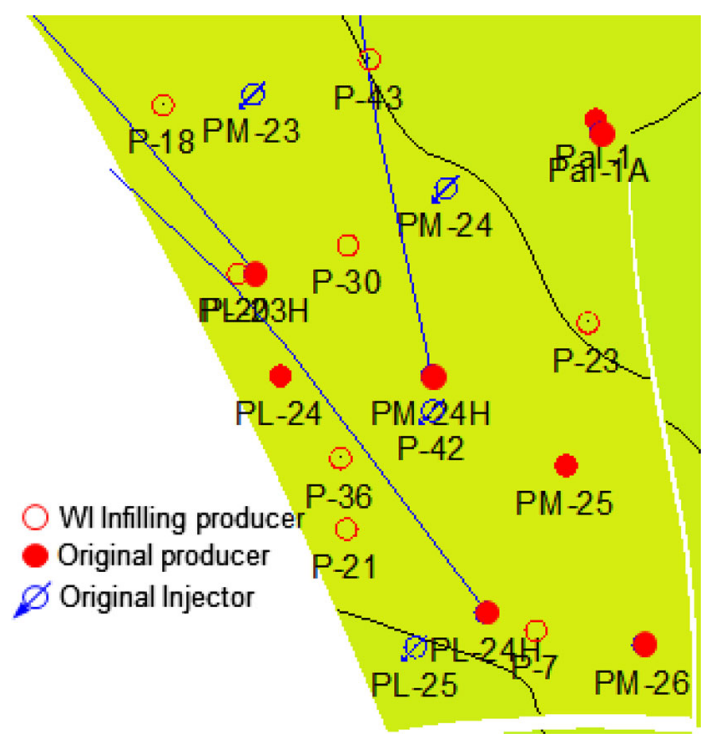

Fig. 3 The well locations of the pilot area

and composite index increase as the polymer concentration increases, and the polymer utilization efficiency increases a little and almost stays constant as polymer concentration rises. Considering the actual well injection ability and lab test results, 2,000 ppm will be recommended.

For SP flooding, it is shown in Table 6 that the chemical efficiency almost stays the same when polymer concentration is larger than $1,600 \mathrm{ppm}$. Considering the degradation effect, $1,800 \mathrm{ppm}$ is recommended. Incremental

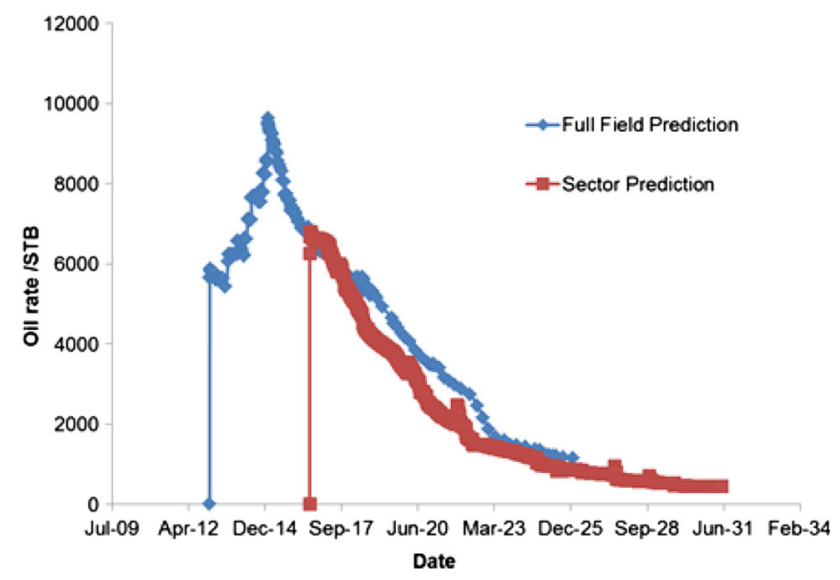

Fig. 4 Pilot oil rate comparison between full field and sector

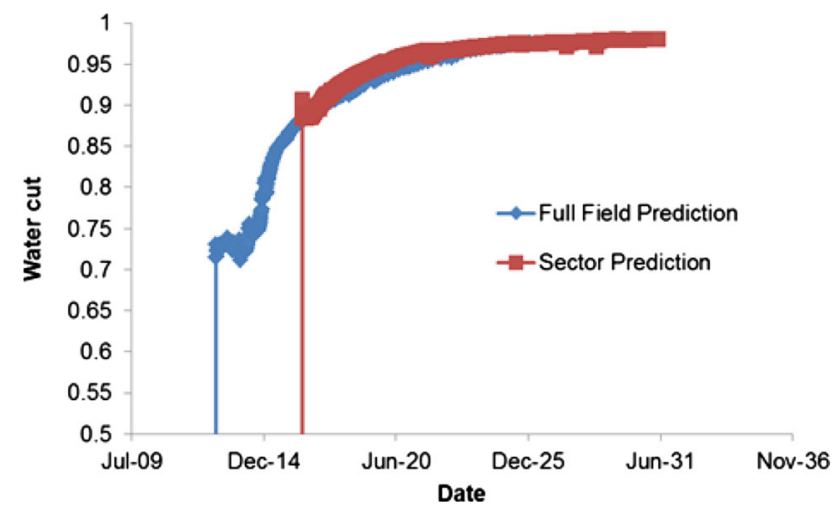

Fig. 5 Pilot water cut comparison between full field and sector

recovery factor increases as the surfactant concentration increases and stays constant when the surfactant concentration exceeds $0.35 \%$. When the surfactant concentration is $0.25-0.35 \%$, the chemical agent efficiency stays on the highest stage. Here the surfactant concentration $0.30 \%$ is recommended. The incremental recovery factor goes up as the injected PV grows. However, the chemical efficiency decreases as the injected PV increases. The composite index increase rate drops apparently from the point $0.3 \mathrm{PV}$, so $0.3 \mathrm{PV}$ is recommended.

For ASP flooding, it is shown in Table 7 that when the polymer concentration exceeds $2,000 \mathrm{ppm}$, the chemical agent efficiency stays almost constant. Considering the severe degradation effect, the 2,000 ppm is recommended. When the surfactant concentration reaches $0.3 \%$, the composite index gets the peak point, so $0.3 \%$ is recommended. The incremental recovery factor slightly climbs as the alkaline concentration increases and reaches the highest value at $0.7 \%$. The chemical agent efficiency decreases as the alkaline concentration increases. According to the relevant field applications, the alkaline concentration $0.1 \%$ is recommended. 
Table 4 The parameter preparation and modifications

\begin{tabular}{|c|c|c|c|}
\hline Type & Parameter & Key words & Modifications from lab to simulator or borrowed data \\
\hline \multirow[t]{4}{*}{ Polymer } & $\begin{array}{l}\text { Polymer solution } \\
\text { viscosity }\end{array}$ & PLYVISC & $\begin{array}{l}\text { Change the polymer viscosity to viscosity multiplier of the water viscosity, then change } \\
\text { the multiplier considering the long-term thermal stability loss ( } 60 \% \text { drop) and long-term } \\
\text { shear loss ( } 7 \% \text { drop), then change the multiplier according to the common field shear } \\
\text { loss (50\% drop) from surface to reservoir }\end{array}$ \\
\hline & Polymer-Rock properties & PLYROCK & Borrowed from the previous study \\
\hline & Polymer adsorption & PLYADS & Borrowed from the previous study \\
\hline & Polymer shear thinning & PLYSHEAR & $\begin{array}{l}\text { Regress the polymer rheological power law index using Carreau model. Then calculate the } \\
\text { average flow velocity using the pore-throat velocity equation. At last, change the } \\
\text { viscosity to the corresponding factor }\end{array}$ \\
\hline \multirow[t]{5}{*}{ Surfactant } & $\begin{array}{l}\text { Surfactant solution } \\
\text { viscosity }\end{array}$ & SURFVISC & $\begin{array}{l}\text { The surfactant solution viscosity is modified according to the eclipse viscosity equation } \\
\text { and keywords format }\end{array}$ \\
\hline & Surfactant adsorption & SURFADS & Borrowed from the previous study \\
\hline & $\begin{array}{l}\text { Surfactant interfacial } \\
\text { tension }\end{array}$ & SURFST & The surfactant interfacial tension is modified according to eclipse keywords format \\
\hline & $\begin{array}{l}\text { Surfactant Capillary } \\
\text { Desaturation }\end{array}$ & SURFCAPD & Borrowed from the previous study \\
\hline & $\begin{array}{l}\text { Surfactant-Rock } \\
\text { properties }\end{array}$ & SURFROCK & Data from the rock PVT data \\
\hline \multirow[t]{5}{*}{ Alkali } & $\begin{array}{l}\text { Alkaline interfacial } \\
\text { tension reduction }\end{array}$ & ALSURFST & $\begin{array}{l}\text { The alkali surface tension reduction is calculated according to the above equation, and the } \\
\text { unit needs to change to the field unit for the eclipse keywords format }\end{array}$ \\
\hline & $\begin{array}{l}\text { Polymer adsorption } \\
\text { reduction by alkali }\end{array}$ & ALPOLADS & Borrowed from the previous study \\
\hline & $\begin{array}{l}\text { Surfactant adsorption } \\
\text { reduction by alkali }\end{array}$ & ALSURFAD & Borrowed from the previous study \\
\hline & Alkaline adsorption & ALKADS & $\begin{array}{l}\text { The alkaline adsorption function is generated by modifying the polymer adsorption } \\
\text { function using the scale factor between the polymer adsorption (same concentration with } \\
\text { the maximum alkali) and the maximum alkali adsorption }\end{array}$ \\
\hline & Alkali-Rock properties & ALKROCK & Data from the rock PVT data \\
\hline
\end{tabular}

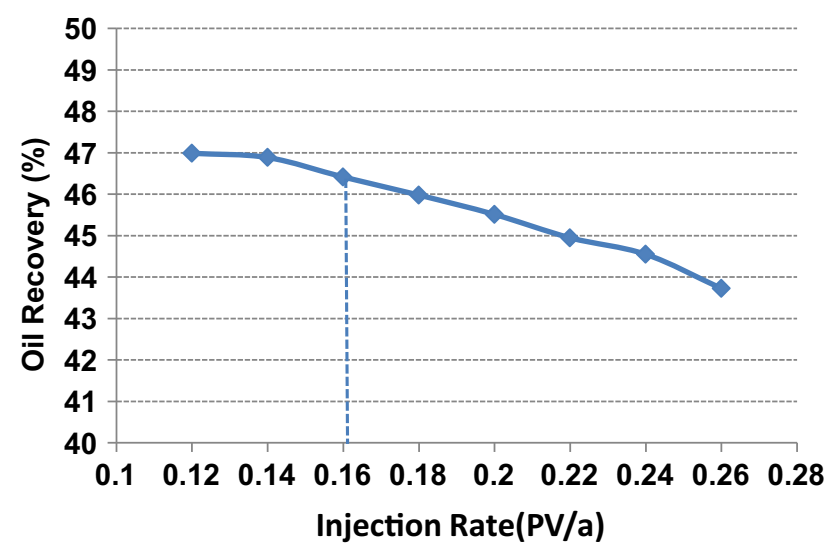

Fig. 6 The sensitivity analysis of water injection rate for Yabus IV and Yabus $\mathrm{V}$

\section{Physiochemical parameter uncertainty}

Some physiochemical data are unavailable from the lab test. In addition, the previous chemical lab data may differ from the actual chemical behavior in fields. So there are some uncertainties in the physiochemical parameters.
Therefore, some key parameters are analyzed by designing three cases (low case, middle case, high case) for each uncertainty parameter. The value for base case comes from field experiences. The detailed case design and the relevant results are listed in the Table 8 .

\section{Uncertainty of residual resistance factor}

The incremental recovery may reduce by $9.6 \%$ on the low side and may increase by $7.4 \%$ on the high side (comparison with middle case). Usually relative big polymer Residual Resistance Factor (RRF) is beneficial for sweep efficiency improvement in polymer flooding. The results indicate that the polymer utilization efficiency increases as the RRF increases and the composite index increases as the RRF increases. It needs to test the polymer RF and RRF to mitigate the uncertainty.

\section{Uncertainty of polymer degradation}

The polymer degradation reduces effective polymer component, and the results show that the incremental recovery 
Table 5 The sensitivity analysis of polymer flooding

\begin{tabular}{|c|c|c|c|c|c|c|}
\hline Cases & $\begin{array}{l}\text { Injection } \\
\text { rate }(\mathrm{PV} / \mathrm{a})\end{array}$ & $\begin{array}{l}\text { Polymer } \\
\text { conc. (ppm) }\end{array}$ & $\begin{array}{l}\text { Pore } \\
\text { volume PV }\end{array}$ & $\begin{array}{l}\text { Incremental } \\
\text { recovery factor }(\%)\end{array}$ & $\begin{array}{l}\text { Chemical utilization } \\
\text { efficiency }(t / t)\end{array}$ & $\begin{array}{l}\text { Composite } \\
\text { index }\end{array}$ \\
\hline $1-1-1$ & 0.16 & 1,600 & 0.4 & 6.96 & 82.55 & 5.74 \\
\hline $1-1-2$ & 0.16 & 1,800 & 0.4 & 7.93 & 85.35 & 6.77 \\
\hline $1-1-3$ & 0.16 & 2,000 & 0.4 & 8.70 & 85.69 & 7.46 \\
\hline $1-1-4$ & 0.16 & 2,200 & 0.4 & 9.45 & 87.21 & 8.24 \\
\hline $1-1-5$ & 0.16 & 2,400 & 0.4 & 10.00 & 88.28 & 8.83 \\
\hline $1-2-1$ & 0.16 & 2,000 & 0.1 & 2.60 & 93.15 & 2.42 \\
\hline $1-2-2$ & 0.16 & 2,000 & 0.2 & 5.40 & 100.92 & 5.45 \\
\hline $1-2-3$ & 0.16 & 2,000 & 0.3 & 7.33 & 95.63 & 7.01 \\
\hline $1-2-4$ & 0.16 & 2,000 & 0.4 & 9.01 & 90.73 & 8.18 \\
\hline $1-2-5$ & 0.16 & 2,000 & 0.5 & 10.20 & 84.36 & 8.61 \\
\hline
\end{tabular}

Table 6 The sensitivity analysis of SP flooding

\begin{tabular}{|c|c|c|c|c|c|c|c|}
\hline Cases & $\begin{array}{l}\text { Injection } \\
\text { rate }(\mathrm{PV} / \mathrm{a})\end{array}$ & $\begin{array}{l}\text { Polymer } \\
\text { conc. (PPM) }\end{array}$ & $\begin{array}{l}\text { Surfactant } \\
\text { conc. }(\%)\end{array}$ & $\begin{array}{l}\text { Pore } \\
\text { volume PV }\end{array}$ & $\begin{array}{l}\text { Incremental } \\
\text { recovery factor }(\%)\end{array}$ & $\begin{array}{l}\text { Chemical utilization } \\
\text { efficiency }(t / t)\end{array}$ & $\begin{array}{l}\text { Composite } \\
\text { index }\end{array}$ \\
\hline $2-1-1$ & 0.16 & 1,400 & 0.3 & 0.3 & 11.27 & 59.78 & 6.74 \\
\hline $2-1-2$ & 0.16 & 1,600 & 0.3 & 0.3 & 12.51 & 63.39 & 7.93 \\
\hline $2-1-3$ & 0.16 & 1,800 & 0.3 & 0.3 & 13.13 & 63.97 & 8.40 \\
\hline $2-1-4$ & 0.16 & 2,000 & 0.3 & 0.3 & 13.58 & 63.66 & 8.64 \\
\hline $2-1-5$ & 0.16 & 2,200 & 0.3 & 0.3 & 14.16 & 64.28 & 9.10 \\
\hline $2-2-1$ & 0.16 & 1,800 & 0.15 & 0.3 & 6.52 & 50.66 & 3.30 \\
\hline $2-2-2$ & 0.16 & 1,800 & 0.2 & 0.3 & 8.48 & 53.19 & 4.51 \\
\hline $2-2-3$ & 0.16 & 1,800 & 0.25 & 0.3 & 11.41 & 62.21 & 7.10 \\
\hline $2-2-4$ & 0.16 & 1,800 & 0.3 & 0.3 & 13.13 & 63.97 & 8.40 \\
\hline $2-2-5$ & 0.16 & 1,800 & 0.35 & 0.3 & 14.41 & 63.47 & 9.15 \\
\hline $2-2-6$ & 0.16 & 1,800 & 0.4 & 0.3 & 14.56 & 58.84 & 8.57 \\
\hline $2-3-1$ & 0.16 & 2,000 & 0.3 & 0.1 & 4.65 & 62.39 & 2.90 \\
\hline $2-3-2$ & 0.16 & 2,000 & 0.3 & 0.2 & 9.87 & 67.70 & 6.68 \\
\hline $2-3-3$ & 0.16 & 2,000 & 0.3 & 0.3 & 13.58 & 63.66 & 8.64 \\
\hline $2-3-4$ & 0.16 & 2,000 & 0.3 & 0.4 & 16.48 & 59.19 & 9.75 \\
\hline $2-3-5$ & 0.16 & 2,000 & 0.3 & 0.5 & 18.70 & 54.76 & 10.24 \\
\hline
\end{tabular}

may increase by $8.4 \%$ on the low side and may decrease by $11.2 \%$ on the high side. The polymer utilization efficiency decreases as the degradation increases. Similarly, the composite index decreases as the degradation increases. Some measures are still needed to reduce degradation in injection process.

\section{Uncertainty of surfactant adsorption}

High surfactant adsorption can cause an SP flood to completely fail. The simulation results indicate that incremental recovery may increase by $3.7 \%$ on the low side and may also decrease by $3.5 \%$ on the high side. The utilization efficiency decreases as the surfactant adsorption increases.
The composite index also decreases as the surfactant adsorption increases. It is needed to test the surfactant adsorption to mitigate the uncertainty.

\section{Uncertainty of Sor reduction}

The uncertainty of Sor reduction has a huge effect on SP flooding. Firstly the relative permeability curves are generated for different Sor according to Corey theory (Corey 1954). The results indicate that the incremental recovery may reduce by $32.7 \%$ on the low side and may also increase by $29.6 \%$ on the high side. The chemical utilization efficiency increases as the Sor reduction increases. The composite index also increases as the Sor reduction 
Table 7 The sensitivity analysis of ASP flooding

\begin{tabular}{|c|c|c|c|c|c|c|c|c|}
\hline Cases & $\begin{array}{l}\text { Injection } \\
\text { rate (PV/a) }\end{array}$ & $\begin{array}{l}\text { Polymer } \\
\text { conc. (ppm) }\end{array}$ & $\begin{array}{l}\text { Surfactant } \\
\text { conc. }(\%)\end{array}$ & $\begin{array}{l}\text { Alkaline } \\
\text { conc. }(\%)\end{array}$ & $\begin{array}{l}\text { Pore } \\
\text { volume PV }\end{array}$ & $\begin{array}{l}\text { Incremental } \\
\text { recovery factor }(\%)\end{array}$ & $\begin{array}{l}\text { Chemical utilization } \\
\text { efficiency }(t / t)\end{array}$ & $\begin{array}{l}\text { Composite } \\
\text { index }\end{array}$ \\
\hline $3-1-1$ & 0.16 & 1,600 & 0.3 & 0.1 & 0.3 & 13.22 & 54.72 & 7.23 \\
\hline $3-1-2$ & 0.16 & 1,800 & 0.3 & 0.1 & 0.3 & 14.30 & 57.40 & 8.21 \\
\hline $3-1-3$ & 0.16 & 2,000 & 0.3 & 0.1 & 0.3 & 15.14 & 58.88 & 8.92 \\
\hline $3-1-4$ & 0.16 & 2,200 & 0.3 & 0.1 & 0.3 & 15.85 & 59.76 & 9.47 \\
\hline $3-1-5$ & 0.16 & 2,400 & 0.3 & 0.1 & 0.3 & 16.46 & 60.22 & 9.91 \\
\hline $3-2-1$ & 0.16 & 2,000 & 0.15 & 0.1 & 0.3 & 12.19 & 63.56 & 7.75 \\
\hline $3-2-2$ & 0.16 & 2,000 & 0.2 & 0.1 & 0.3 & 13.52 & 63.29 & 8.56 \\
\hline $3-2-3$ & 0.16 & 2,000 & 0.25 & 0.1 & 0.3 & 14.41 & 61.22 & 8.82 \\
\hline $3-2-4$ & 0.16 & 2,000 & 0.3 & 0.1 & 0.3 & 15.14 & 58.88 & 8.92 \\
\hline $3-2-5$ & 0.16 & 2,000 & 0.35 & 0.1 & 0.3 & 15.55 & 55.77 & 8.67 \\
\hline $3-2-6$ & 0.16 & 2,000 & 0.4 & 0.1 & 0.3 & 15.85 & 52.73 & 8.36 \\
\hline $3-3-1$ & 0.16 & 2,000 & 0.3 & 0.02 & 0.3 & 14.65 & 66.03 & 9.67 \\
\hline $3-3-2$ & 0.16 & 2,000 & 0.3 & 0.05 & 0.3 & 14.68 & 61.42 & 9.02 \\
\hline $3-3-3$ & 0.16 & 2,000 & 0.3 & 0.1 & 0.3 & 15.14 & 58.88 & 8.92 \\
\hline $3-3-4$ & 0.16 & 2,000 & 0.3 & 0.2 & 0.3 & 15.27 & 50.88 & 7.77 \\
\hline $3-3-5$ & 0.16 & 2,000 & 0.3 & 0.3 & 0.3 & 15.58 & 45.41 & 7.08 \\
\hline $3-3-6$ & 0.16 & 2,000 & 0.3 & 0.4 & 0.3 & 15.89 & 41.15 & 6.54 \\
\hline $3-3-7$ & 0.16 & 2,000 & 0.3 & 0.5 & 0.3 & 16.05 & 37.40 & 6.00 \\
\hline $3-3-8$ & 0.16 & 2,000 & 0.3 & 0.7 & 0.3 & 16.05 & 31.13 & 5.00 \\
\hline $3-3-9$ & 0.16 & 2,000 & 0.3 & 1.0 & 0.3 & 15.67 & 24.28 & 3.80 \\
\hline $3-4-1$ & 0.16 & 2,000 & 0.3 & 0.1 & 0.1 & 5.64 & 62.93 & 3.55 \\
\hline $3-4-2$ & 0.16 & 2,000 & 0.3 & 0.1 & 0.2 & 10.84 & 61.99 & 6.72 \\
\hline $3-4-3$ & 0.16 & 2,000 & 0.3 & 0.1 & 0.3 & 15.14 & 58.88 & 8.92 \\
\hline $3-4-4$ & 0.16 & 2,000 & 0.3 & 0.1 & 0.4 & 17.90 & 53.07 & 9.50 \\
\hline $3-4-5$ & 0.16 & 2,000 & 0.3 & 0.1 & 0.5 & 20.24 & 48.60 & 9.84 \\
\hline
\end{tabular}

increases. The SP/ASP oil-water relative permeability curves should be tested in lab and field to derisk the uncertainty.

\section{Pilot development scenarios comparisons}

EOR development scenarios are designed according to the lab results, sensitivity results, and field experiences. Then the performance is predicted for potential technical evaluation for pilot test (Moreno et al. 2003). The chemical pilot will help mitigate risks and uncertainties by collecting the pilot application data.

\section{Water injection scenario}

The water injection case is the water flooding using the same well pattern originated from the zonal injection plan for the sector. It is shown in Fig. 3 that there are four injectors and sixteen producers. Obviously, the well spacing is a little bit wider and the well pattern is not mature for chemical flooding. So we design an infilling case which infill two producers and two injectors. The detailed information of the infilling well pattern can be seen in Fig. 7.

\section{Chemical flooding scenarios}

The chemical flooding scenarios will be conducted on the base of the infilling water flooding case. The cases' slug composition details are illustrated in Table 9. Three cases (P/SP/ASP) will be run to see the enhanced oil potential. Figure 8 shows the water cut and stage EOR variances within 1 injected PV for different cases. The sector EOR potential is evaluated for the target zones as shown in Table 10. The ASP has the highest incremental recovery factor $(19.53 \%)$, and the polymer has the lowest incremental recovery factor $(14.31 \%)$. The polymer has the highest agent efficiency (44.08 t/t), and ASP has the lowest agent efficiency $(13.71 \mathrm{t} / \mathrm{t})$. The polymer has the highest composite index, and the ASP flooding has the lowest composite index. In order to evaluate the preliminary chemical EOR technical feasibility, two EOR potential 
Table 8 The cases of physiochemical parameter uncertainty

\begin{tabular}{|c|c|c|c|c|c|c|c|}
\hline Cases & RRF & $\begin{array}{l}\text { Polymer } \\
\text { degradation (\%) }\end{array}$ & $\begin{array}{l}\text { Surfactant } \\
\text { adsorption (lb/lb) }\end{array}$ & $\begin{array}{l}\text { Sor reduction } \\
(\%)\end{array}$ & $\begin{array}{l}\text { EOR } \\
(\%)\end{array}$ & $\begin{array}{l}\text { Chemical } \\
\text { efficiency }(t / t)\end{array}$ & $\begin{array}{l}\text { Composite } \\
\text { index }\end{array}$ \\
\hline $1-1$ & 2 & 50 & - & - & 7.85 & 76.02 & 5.97 \\
\hline $1-2$ & 2.5 & 50 & - & - & 8.68 & 85.46 & 7.41 \\
\hline $1-3$ & 3 & 50 & - & - & 9.32 & 93.53 & 8.72 \\
\hline $2-1$ & 2.5 & 40 & - & - & 9.41 & 94.55 & 8.90 \\
\hline $2-2$ & 2.5 & 50 & - & - & 8.68 & 85.46 & 7.41 \\
\hline $2-3$ & 2.5 & 60 & - & - & 7.71 & 74.60 & 5.75 \\
\hline $3-1$ & 2.5 & 50 & 0.0000621 & 100 & 13.63 & 66.35 & 9.05 \\
\hline $3-2$ & 2.5 & 50 & 0.0001035 & 100 & 13.14 & 63.99 & 8.41 \\
\hline $3-3$ & 2.5 & 50 & 0.0001449 & 100 & 12.68 & 61.80 & 7.83 \\
\hline $4-1$ & 2.5 & 50 & 0.0001035 & 60 & 7.45 & 36.59 & 2.73 \\
\hline $4-2$ & 2.5 & 50 & 0.0001035 & 75 & 10.21 & 49.91 & 5.09 \\
\hline $4-3$ & 2.5 & 50 & 0.0001035 & 90 & 13.04 & 63.52 & 8.28 \\
\hline
\end{tabular}

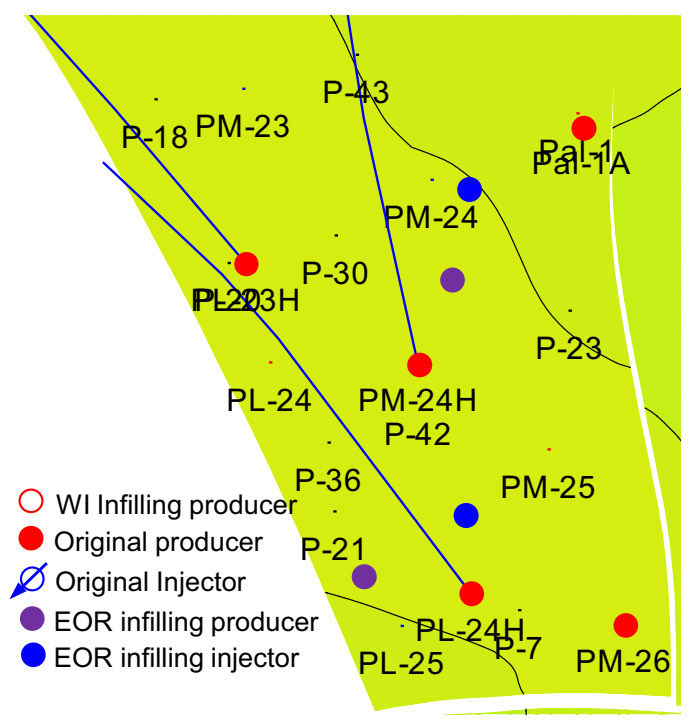

Fig. 7 The well pattern of the infilling scenario

data are collected, one is the EOR when the water cut exceeds $98 \%$ EOR and the other is the EOR at the end of 2025. The main information is listed in Table 11.

The chemical EOR is relatively high, which indicates the good feasibility. The ASP achieves the highest EOR, followed by SP, and the Polymer is the lowest. The incremental oil and EOR at the end of 2025 is higher than those when the water cut exceeds $98 \%$. The reason is that the production of the water flooding is much longer in the first situation than in second situation, which means more oil production for water injection in first situation. The chemical cost per incremental oil for ASP case is highest followed by SP, and the lowest is polymer flooding.

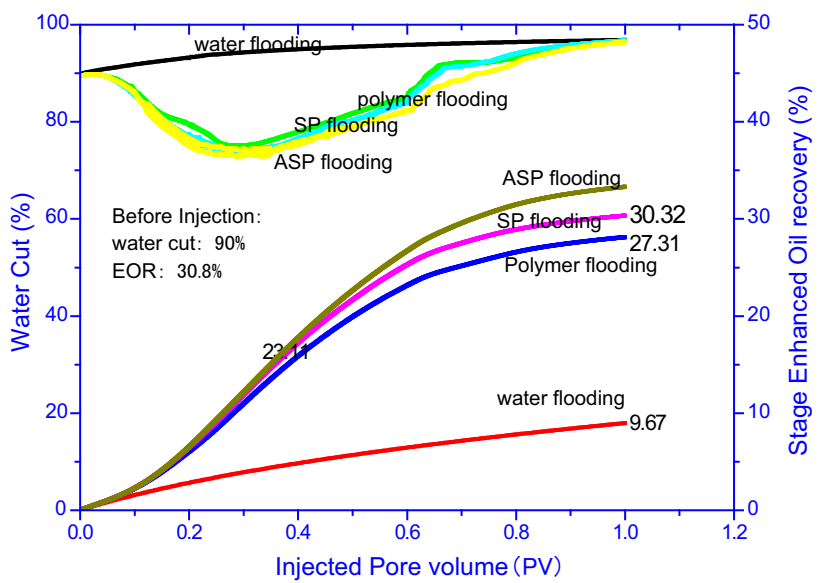

Fig. 8 The water cut and stage EOR of different cases within 1 injected PV

\section{EOR technical feasibility evaluation}

By combining the EOR screening and EOR simulation study, the polymer flooding is recommended. Polymer flooding is technically and commercially mature, especially in Daqing oilfield, China (Wang and Liu 2006). Polymer has simple component and is convenient to use. Lower costs and lower risks and uncertainties were compared to SP or ASP. A huge investment in facility and chemical leads to limited SP/ASP feasibility. What's more, there are some severe technical risks such as adsorption, corrosion, precipitation, and emulsion of the produced fluid. More operational risks such as the chemical supply and surveillance are also considered for SP/ASP flooding.

But polymer flooding also has some risks for Palouge Structure. Until now, there is no successful field application 
Table 9 The cases' slug composition is illustrate as the following table

\begin{tabular}{|c|c|c|c|c|}
\hline Cases & Preflush slug & Main slug & Auxiliary slug & $\begin{array}{l}\text { Protection } \\
\text { slug }\end{array}$ \\
\hline $\begin{array}{l}\text { Polymer } \\
\text { flooding }\end{array}$ & - & $\begin{array}{l}0.45 \text { PV } \\
2000 \text { PPM polymer }\end{array}$ & - & $\begin{array}{l}0.15 \mathrm{PV} \\
1800 \mathrm{PPM} \\
\text { polymer }\end{array}$ \\
\hline SP flooding & $\begin{array}{l}0.05 \text { PV } 2000 \mathrm{PPM} \\
\text { polymer }\end{array}$ & $\begin{array}{l}0.30 \mathrm{PV} \\
2000 \mathrm{PPM} \text { polymer }+0.3 \% \text { surfactant }\end{array}$ & $\begin{array}{l}0.15 \mathrm{PV} \\
2000 \mathrm{PPM} \text { polymer }+0.1 \% \text { surfactant }\end{array}$ & $\begin{array}{l}0.10 \mathrm{PV} \\
1800 \mathrm{PPM} \\
\text { polymer }\end{array}$ \\
\hline $\begin{array}{l}\text { ASP } \\
\text { flooding }\end{array}$ & $\begin{array}{l}0.05 \text { PV } 2000 \mathrm{PPM} \\
\text { polymer }\end{array}$ & $\begin{array}{l}0.30 \mathrm{PV} \\
2000 \mathrm{PPM} \text { polymer }+0.3 \% \text { surfactant } \\
\quad+1.2 \% \text { alkaline }\end{array}$ & $\begin{array}{l}0.15 \mathrm{PV} \\
2000 \mathrm{PPM} \text { polymer }+0.1 \% \text { surfactant } \\
\quad+1.0 \% \text { alkaline }\end{array}$ & $\begin{array}{l}0.10 \mathrm{PV} \\
1800 \mathrm{PPM} \\
\text { polymer }\end{array}$ \\
\hline
\end{tabular}

Table 10 The summary of sector EOR potential

\begin{tabular}{llllllrrr}
\hline Cases & $\begin{array}{l}\text { Sector STOIIP } \\
\text { MMSTB }\end{array}$ & $\begin{array}{l}\text { Target STOIIP } \\
\text { MMSTB }\end{array}$ & $\begin{array}{l}\text { Target pore volume } \\
\text { MMRB }\end{array}$ & $\begin{array}{l}\text { Injection rate } \\
\text { PV/year }\end{array}$ & $\begin{array}{l}\text { Inc. RF } \\
\%\end{array}$ & $\begin{array}{l}\text { Inc. oil } \\
\text { MMSTB }\end{array}$ & $\begin{array}{l}\text { Chemical } \\
\text { efficiency } \\
\text { t/t }\end{array}$ & $\begin{array}{l}\text { Comp. } \\
\text { index }\end{array}$ \\
\hline Polymer flooding & 75.36 & 29.28 & 39.55 & 0.16 & 14.31 & 4.19 & 44.08 & 6.43 \\
SP flooding & 75.36 & 29.28 & 39.55 & 0.16 & 16.35 & 4.79 & 34.71 & 6.01 \\
ASP flooding & 75.36 & 29.28 & 39.55 & 0.16 & 19.53 & 5.72 & 13.17 & 2.68 \\
\hline
\end{tabular}

Table 11 The information for the preliminary EOR feasibility evaluation

\begin{tabular}{|c|c|c|c|c|c|c|}
\hline \multirow[t]{2}{*}{ Simulation stop date } & \multicolumn{3}{|c|}{ Water cut $>98 \%$} & \multicolumn{3}{|c|}{ Date 2025} \\
\hline & $\mathrm{P}$ & SP & ASP & $\mathrm{P}$ & SP & ASP \\
\hline Daqing field EOR & 10.4 & 16.28 & 20.13 & - & - & - \\
\hline Pilot EOR & 14.31 & 16.35 & 19.53 & 17.94 & 20.09 & 23.15 \\
\hline Chemical cost* (MM\$) & 26.97 & 53.36 & 92.20 & 26.97 & 53.36 & 92.20 \\
\hline Incremental oil (MMSTB) & 4.19 & 4.79 & 5.72 & 5.25 & 5.88 & 6.78 \\
\hline Chemical Cost Per Inc. Oil (\$/STB) & 6.44 & 11.14 & 16.13 & 5.13 & 9.07 & 13.60 \\
\hline
\end{tabular}

* The chemical unit cost is polymer $(1.67 \$ / 1 \mathrm{~b})$, surfactant $(1.84 \$ / 1 \mathrm{~b})$, alkali $(0.60 \$ / 1 \mathrm{~b})$

for polymer flooding in high temperature reservoir (especial above $80^{\circ} \mathrm{C}$ ) in China. Other issues are polymer shearing degradation in the injection process and injection sweep efficiency (uncertain sand connectivity and heterogeneity). Facilities also require rejuvenation to maintain integrity and improve produced fluid treatment (water softening). In addition, it still needs economic evaluation to optimize chemical scenarios.

\section{Conclusions}

(1) EOR screening was performed for the main oilbearing zones using the SPE EOR screening criteria. The pilot selection was determined based on zonal injection plan and application experiences. Yabus IV and Yabus $\mathrm{V}$ are chosen as the target zones.
(2) The P/SP/ASP flooding with different injection time, injected pore volume, chemical (polymer/surfactant/ alkali) concentration, and injection rate are carried out. The recommended slug compositions are designed and some physicochemical data uncertainties were also analyzed by conducting the high/middle/ low cases.

(3) Four scenarios (water injection scenario, polymer flooding, SP flooding, and ASP flooding) are simulated for the pilot area, the incremental oil recovery result is ASP $(19.53 \%)>\mathrm{SP} \quad(16.35 \%)>\mathrm{P}$ $(14.31 \%)$. After technical evaluation, polymer flooding case is recommended for future pilot test.

Acknowledgments This study was supported by the Dar Petroleum Operating Company (DPOC) to whom we express our deep gratitude and appreciation. This work was also sponsored by the National 
Natural Science Foundation (Grant No. 40974056) in China, which is studying on the particle gel profile control technology. This work is also supported by PCSIRT (IRT1294). In the last, many thanks are indebted to RIPED to supply the Eclipse software for simulation study.

Open Access This article is distributed under the terms of the Creative Commons Attribution 4.0 International License (http:// creativecommons.org/licenses/by/4.0/), which permits unrestricted use, distribution, and reproduction in any medium, provided you give appropriate credit to the original author(s) and the source, provide a link to the Creative Commons license, and indicate if changes were made.

\section{References}

Al-Adasani A, Bai B (2010) Recent developments and updated screening criteria of enhanced oil recovery techniques. International oil and gas conference and exhibition in China. Society of Petroleum Engineers

Al-Mutairi SM, Kokal SL (2011) EOR potential in the Middle East: current and future trends. SPE EUROPEC/EAGE annual conference and exhibition. Society of Petroleum Engineers

Alvarado V et al (2011) Stability proxies for water-in-oil emulsions and implications in aqueous-based enhanced oil recovery. Energies 4(7):1058-1086

Alvarado V, Manrique E (2010) Enhanced oil recovery: an update review. Energies 3(9):1529-1575

Chang $\mathrm{H}$ et al (2006) Advances in polymer flooding and alkaline/surfactant/polymer processes as developed and applied in the People's Republic of China. J Pet Technol 58(2):84-89

Corey AT (1954) The interrelation between gas and oil relative permeabilities. Producers Mon 19(1):38-41

$\mathrm{Gu} \mathrm{H}$ et al (1998) Study on reservoir engineering: ASP flooding pilot test in Karamay oilfield. SPE international oil and gas conference and exhibition in China. Society of Petroleum Engineers

Hongyan W et al (2009) Development and application of dilute surfactant-polymer flooding system for Shengli oilfield. J Pet Sci Eng 65(1):45-50

Koning E et al (1988) Evaluation of a pilot polymer flood in the Marmul field Oman. SPE annual technical conference and exhibition. Society of Petroleum Engineers

$\mathrm{Li} \mathrm{H}$ et al (2003) Alkline/surfactant/polymer (ASP) commercial flooding test in central Xing2 area of Daqing oilfield. SPE international improved oil recovery conference in Asia Pacific. Society of Petroleum Engineers

Li Y et al (2008) Current status and prospects of ASP flooding in Daqing oil fields. SPE symposium on improved oil recovery. Society of Petroleum Engineers
Maheshwari YK (2011) A comparative simulation study of chemical EOR methodologies (alkaline, surfactant and/or polymer) applied to Norne Field E-segment. Master thesis, NTNU

Manrique E et al (2000) Alkali/surfactant/polymer at VLA 6/9/21 field in Maracaibo lake: experimental results and pilot project design. SPE/DOE improved oil recovery symposium. Society of Petroleum Engineers

Manrique EJ et al (2010) EOR: current status and opportunities. SPE improved oil recovery symposium. Society of Petroleum Engineers

Meyers J et al (1992) Alkaline-surfactant-polymer flood of the West Kiehl Minnelusa unit. SPE/DOE enhanced oil recovery symposium. Society of Petroleum Engineers

Moreno R et al (2003) Comparative mechanistic simulations to design an ASP field pilot in La Salina Venezuela. Canadian international petroleum conference. Petroleum Society of Canada

Pitts MJ et al (2006) Alkaline-surfactant-polymer flood of the Tanner Field. SPE/DOE symposium on improved oil recovery. Society of Petroleum Engineers

$\mathrm{Pu} \mathrm{H}$ (2009) An update and perspective on field-scale chemical floods in Daqing Oilfield China. SPE Middle East oil and gas show and conference. Society of Petroleum Engineers

Sandoval JR et al (2010) Dina Cretaceo field chemical EOR: from screening to pilot design. SPE Latin American and Caribbean petroleum engineering conference. Society of Petroleum Engineers

Sandrea I, Sandrea R (2007) Global oil reserves-1: recovery factors leave vast target for EOR technologies. Oil Gas J 105(41):44

Spildo K et al (2009) A new polymer application for North Sea reservoirs. SPE Reserv Eval Eng 12(03):427-432

Taber JJ et al (1996) EOR screening criteria revisited. Symposium on improved oil recovery, pp 387-415

Taber $\mathbf{J}$ et al (1997) EOR screening criteria revisited-part 2: applications and impact of oil prices. SPE Reserv Eng 12(03):199-206

Thomas S (2008) Enhanced oil recovery-an overview. Oil Gas Sci Technol Revue de l'IFP 63(1):9-19

Vargo J et al (2000) Alkaline-surfactant-polymer flooding of the Cambridge Minnelusa Field. SPE Reserv Eval Eng 3(06):552-558

Wang Y, Liu H (2006) Commercial success of polymer flooding in Daqing Oilfield-lessons learned. Paper SPE100855-MS presented at the SPE Asia Pacific oil \& gas conference and exhibition, Adelaide, Australia, pp 11-13

Wassmuth F et al (2009) Polymer flood application to improve heavy oil recovery at East Bodo. J Can Pet Technol 48(2):55

Worldwide E (2010) Survey special report: EOR/heavy oil survey. Oil Gas J 108(14):1-13

Yeow Chong Y et al (2013) Chemical EOR evaluation for GNPOC and PDOC fields in Sudan. SPE enhanced oil recovery conference. Society of Petroleum Engineers 